\title{
A cluster of KPC-2 and VIM-2-producing Klebsiella pneumoniae ST833 isolates from the pediatric service of a Venezuelan Hospital
}

\author{
Aura Falco ${ }^{1}$, Yusibeska Ramos ${ }^{2}$ Esther Franco ${ }^{3}$, Alegría Guzmán ${ }^{3}$ and Howard Takiff ${ }^{*}$
}

\begin{abstract}
Background: Klebsiella pneumoniae is a bacterial pathogen that has developed resistance to multiple antibiotics and is a major cause of nosocomial infections worldwide. Carbapenemase-producing Klebsiella pneumoniae have been isolated in many hospitals in Venezuela, but they have not been well-studied. The aim of this study was to characterize carbapenem-resistant Klebsiella pneumoniae isolates from the pediatric service of a hospital located in Anzoategui State, in the eastern part of Venezuela.

Methods: Nineteen Klebsiella pneumoniae strains isolated in the hospital from April to July 2014 were evaluated phenotypically and molecularly for the presence of carbapenemases blaKPC, blalMP and blaVIM. Molecular epidemiology was performed with Repetitive Extragenic Palindromic-PCR (REP-PCR) and Multilocus Sequence Typing (MLST). They were also studied for phenotypic and molecular resistance to a quaternary ammonium compound (QAC) disinfectant.

Results: All 19 isolates contained both bla $a_{\mathrm{VIM}-2}$ and b/a $a_{\mathrm{KPC}-2}$ genes, and the bla $a_{\mathrm{KPC}-2}$ gene was associated with Tn4401 b. All isolates were phenotypically sensitive to QACs and contained qac $\Delta \mathrm{E}$ and addA2 genes typical of class 1 integrons. Analysis by REP-PCR and MLST showed that all isolates had identical profiles characteristic of sequence type ST833.

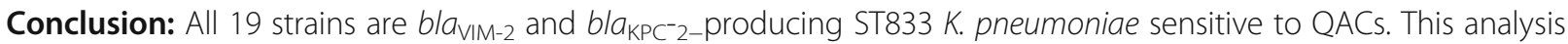
may help to understand the routes of dissemination and confirms that QAC disinfectants can be used to help control their spread.
\end{abstract}

Keywords: Klebsiella pneumoniae, carbapenem, resistance, ST833

\section{Background}

The emergence of plasmid-mediated carbapenem hydrolyzing $\beta$-lactamases and their spread amongst Gramnegative bacteria, especially Klebsiella pneumoniae, has become a serious threat for hospitalized patients worldwide. The two principal types of acquired carbapenemases are the molecular class B metallo- $\beta$-lactamases (MBLs) and the molecular class A $K$. pneumoniae

\footnotetext{
* Correspondence: htakiff@ivic.gob.ve

'Laboratorio de Genética Molecular, Centro de Microbiología y Biología

Celular, Instituto Venezolano de Investigaciones Científicas, Caracas, Venezuela

Full list of author information is available at the end of the article
}

carbapenemases (KPCs), both of which have been detected in many countries [1-4]. The bla $a_{\mathrm{VIM}}$ gene encodes a transferable carbapenemase and is generally found within class 1 integrons. Although originally identified in Pseudomonas aeruginosa, VIM enzymes are now endemic within Enterobacteriaceae [5, 6]. The $b l a_{\mathrm{KPC}}$ genes are usually located within Tn4401 [7], a Tn3-based transposon harbored on plasmids or in the chromosome. In recent years carbapenem-resistant $K$. pneumoniae has become a frequent cause of nosocomial infections in several hospitals in different Venezuelan cities [8], but the epidemiology, molecular epidemiology, clinical impact and carbapenemase genes of Venezuelan 
carbapenemase-producing $K$. pneumoniae have not been described. In this study we characterize 19 carbapenemaseproducing K. pneumoniae isolates associated with nosocomial infections centered in the pediatric service of a large Venezuelan tertiary-care public hospital. All 19 isolates contained both $b l a_{\mathrm{VIM}-2}$ and $b l a_{\mathrm{KPC}-2}$ genes, were phenotypically sensitive to QACs and contained qac $\triangle \mathrm{E}$ and addA2 genes typical of class 1 integrons. Analysis by REPPCR and MLST showed that all isolates had identical profiles characteristic of sequence type ST833.

\section{Methods}

\section{Hospital setting}

The "Rafael Tobías Guevara" Pediatrics Department is part of the "Dr. Luis Razetti" Hospital, a large tertiary-care public hospital with 502 beds, located in Anzoátegui State, in the eastern part of Venezuela. The "Rafael Tobías Guevara" Pediatrics Department has 73 beds in the neonatal unit, 3 delivery rooms, 28 beds in the neonatal intermediate care unit and 12 beds in the neonatal intensive care unit. In 2014 nearly 26,000 women gave birth in this hospital, $30 \%$ of whom were adolescents.

\section{Study population}

The study was conducted from April to July 2014 and included all carbapenem-resistant Klebsiella pneumoniae strains isolated from pediatric patients hospitalized in the "Rafael Tobías Guevara" Pediatrics Department during this period. If there were more than one isolate from a patient, only the first was included in the study. Information on the source of the clinical specimen, the patient's age, gender and hospital location was obtained from specimen records in the bacteriology laboratory and made irreversibly anonymous. The Bioethics Commission of the Instituto Venezolano de Investigaciones Científicas determined that the study did not require its approval.

\section{Bacterial strains and antibiotic susceptibility testing}

The study included 19 Klebsiella pneumoniae strains isolated from April to July 2014 in the bacteriology laboratory of the "Rafael Tobías Guevara" Pediatrics Department. They all showed intermediate or full resistance to carbapenems according to the Clinical and Laboratory Standards Institute (CLSI) 2014 cutoff points [9]. The broader antimicrobial susceptibility profile of the Klebsiella pneumoniae strains was determined by the broth dilution method according to the CLSI guidelines for the following antibiotics: amikacin, tetracycline, chloramphenicol, amoxicillin/clavulanic acid, ampicillin, ampicillin/sulbactam, cefalotin, cefoxitin, ceftazidime, cefepime, piperacillin, piperacillin/tazobactam, aztreonam, cefoperazone/sulbactam, imipenem, meropenem, ciprofloxacin, and trimethoprim/sulfamethoxazole. Carbapenemase activity in all 19 isolates was confirmed by the Hodge test [9]. The disk diffusion assay with ertapenem and 3-aminophenyl boronic acid (400 $\mu \mathrm{g}$ ) was used to confirm the presence of KPC-type $\beta$-lactamases [10], and with ertapenem and EDTA to confirm the presence of metallo- $\beta$-lactamases in all 19 isolates.

\section{Detection of genes encoding $\beta$-lactamases and their genetic environment, integron cassettes and efflux pumps}

Bacterial strains were grown on MacConkey agar and incubated overnight at $37{ }^{\circ} \mathrm{C}$. One colony was resuspended in $100 \mu \mathrm{l}$ of sterile distilled water and the bacteria were lysed by heating at $100{ }^{\circ} \mathrm{C}$ for $10 \mathrm{~min}$. Cellular debris was removed by centrifugation at $13,000 \mathrm{~g}$ for $10 \mathrm{~min}$ and the supernatant was used as template DNA for PCR amplifications [11].

The carbapenemase genes $b l a_{\mathrm{KPC}}$ [12] $b l a_{\mathrm{IMP}}$ and $b l a_{\mathrm{VIM}}$ [13] were amplified by PCR using the primers listed in Additional file 1: Table S1. The genetic environment of the $b l a_{\mathrm{KPC}}$ genes was determined by PCR using previously described primers [14] specific for the Tn4401 transposon (Additional file 1: Table S1). To detect the qac $\Delta \mathrm{E}$ gene encoding a putative efflux pump often found in class 1 integrons [15] as well as other integron cassettes [16], PCR was performed using primers specific for the $5^{\prime}$ and $3^{\prime}$ conserved integrons segments (Additional file 1: Table S1). PCR was also used for to detect putative efflux pumps qacA, $q a c \mathrm{~B}$ [15] and $q a c \mathrm{C}$ genes [17] (Additional file 1: Table S1). The positive controls for the PCR reactions were characterized by phenotypic testing and PCR followed by sequencing of the relevant genes: a KPC-producing $K$. pneumoniae strain carrying a bla $a_{\mathrm{KPC}}$ gene; a IMPproducing $P$. aeruginosa strain carrying a $b l a_{\mathrm{IMP}}$ gene; a $P$. aeruginosa strain carrying a bla $a_{\mathrm{VIM}}$ gene; and 4 isolates of A. baumannii resistant to QACs disinfectans carrying $q a c \mathrm{~A}, q a c \mathrm{~B}, q a c \mathrm{C}$ and $q a c \Delta \mathrm{E}$ genes, respectively.

After PCR amplification, amplified fragments from the 19 clinical isolates were purified with Qiaquick PCR Spin columns (Qiagen) and sequenced in both forward and reverse directions (Macrogen, Korea) with the same primers used for PCR amplification. The sequences were compared with the National Center for Biotechnology Information (NCBI) (https://blast.ncbi.nlm.nih.gov/Blast.cgi) and Lahey databases (http://www.lahey.org/Studies/).

\section{Disinfectant susceptibility test in Klebsiella pneumoniae isolates}

Susceptibility to Quaternary Ammonium Compounds (QACs) was determined using the quantitative suspension test for bactericidal activity, according to the protocol of Kawamura-Sato [18, 19]. The test was performed with the commercial disinfectant most commonly used in Venezuelan hospitals [20], which contains $10 \%$ lauryl dimethyl benzyl ammonium bromide as the active QAC agent. 


\section{Molecular genotyping}

The genetic relationships amongst the 19 carbapenemresistance isolates were determined by Repetitive Element Palindromic-PCR (REP-PCR) and Multi-Locus Sequence Typing (MLST). REP-PCR was performed using previously described primers REP1 and REP2 [21] (Additional file 1: Table S1). MLST was performed using the methodology described by Diancourt et al. [22] (Additional file 1: Table S1). After PCR amplification, the fragments were sequenced with the amplification primers in the forward and reverse directions by Macrogen, Korea. Allele numbers and sequence types (STs) were assigned by the Klebsiella pneumoniae MLST web site (http://bigsdb.pasteur.fr/ klebsiella/klebsiella.html).

\section{Plasmid analysis}

Plasmid DNA was extracted by the Kieser extraction method [23] and analyzed by gel electrophoresis in $0.7 \%$ agarose.

\section{Results}

\section{Clinical and epidemiological characteristics}

We analyzed 19 carbapenem-resistant K. pneumoniae strains isolated from clinical specimens of an equal number of patients in the "Rafael Tobías Guevara" Pediatrics Department located in the "Dr. Luis Razetti" Teaching Hospital. The patients' demographic and clinical characteristics are summarized in Table 1. All infections were health care associated. Fourteen patients $(n=14 / 19$, $73.7 \%)$ were newborns and $12(n=12 / 19,63.1 \%)$ were male. The most common infection sites were bloodstream $(n=15 / 19,79 \%)$ and bronchial secretions $(n=2 /$ 19, $10.5 \%$ ) (Table 1).

\section{Antibiotic susceptibility testing of $K$. pneumoniae isolates} All 19 isolates were resistant to trimethoprim-sulfamethoxazole, imipenem and meropenem, but testing for resistance to other antibiotics revealed seven resistance profiles. Profiles 2 and 5 were the most common with four isolates each, followed by profiles 1 and 4 with three isolates each (Table 2). The isolates in profile 7, the most resistant, were not sensitive to any of antibiotics tested, while profile 2 isolates were the most sensitive, showing resistance only to ciprofloxacin (Table 2). The percentages of isolates resistant to other antibiotics were: amikacin, $63.2 \%$; ciprofloxacin, $94.7 \%$; tetracycline, $84.2 \%$; chloramphenicol, $42.1 \%$; and tigecycline $15.8 \%$.

\section{Detection of genes encoding $\beta$-lactamases}

Using PCR, both the $b l a_{\mathrm{KPC}-2}$ and $b l a_{\mathrm{VIM}-2}$ genes were detected in $100 \%(n=19 / 19)$ of the isolates, while the blaIMP gene could not be amplified from any isolate.
Table 1 Clinical characteristics of patients infected by carbapenem-resistant $K$. pneumoniae isolates from a Venezuelan Hospital

\begin{tabular}{lr}
\hline $\begin{array}{l}\text { Characteristic } \\
\text { Gender }\end{array}$ & $\begin{array}{c}\text { No. (\%) of isolates } \\
\text { Total no. }\end{array}$ \\
Female & $7(36.9 \%)$ \\
Male & $12(63.1 \%)$ \\
Age & \\
Newborn (0-6 days) & $14(73.7 \%)$ \\
Lower infant (1-12 months) & $2(10.5 \%)$ \\
Higher infant (1-2 years) & $2(10.5 \%)$ \\
School (5-10 years) & $1(5.3 \%)$ \\
Infection site & \\
Bloodstream & $15(79 \%)$ \\
Bronchial secretion & $2(10.4 \%)$ \\
Catheter & $1(5.3 \%)$ \\
Lesion secretion & $1(5.3 \%)$ \\
Hospitalization área & \\
Neonatal & $12(63.2 \%)$ \\
Internal medicine & $2(10.5 \%)$ \\
Intensive care & $2(10.5 \%)$ \\
Surgery & $3(15.8 \%)$ \\
\hline
\end{tabular}

Genetic environment of $b / a_{\mathrm{KPC}}$ gene

The $b l a_{\mathrm{KPC}}$ gene is generally associated with a Tn3-based transposon, Tn4401, composed of a transposase gene, a resolvase gene, the $b l a_{\mathrm{KPC}}$ gene and two insertion sequences (ISKpn6 and ISKpn7) [7]. Six isoforms of Tn4401 have been identified which differ by various deletions upstream of the $b l a_{\mathrm{KPC}}$ gene $[24,25]$. Amplification of the regions flanking the $b l a_{\mathrm{KPC}-2}$ genes with $T n 4401$ specific primers [14] produced a 703-bp PCR fragment from all 19 isolates, consistent with the Tn4401 variant "b" [14] (Fig. 1). The ISKpn6 and tnpA genes were also amplified separately from all 19 isolates, but the inverted repeat sequences of Tn4401 could not be amplified with primers specific for this region $[7,14,26]$ (Additional file 1: Table S1).

\section{Detection of genes located in class 1 integrons}

Amplification and sequencing with primers specific for class 1 integrons detected $q a c \Delta \mathrm{E}$ and $a d d \mathrm{~A} 2$ genes in all 19 isolates. The addA2 gene encodes an aminoglycoside adenyltransferase that confers streptomycin resistance, while qac $\Delta \mathrm{E}$ gene encodes a truncated Quaternary Ammonium Compounds resistance protein.

Disinfectant susceptibility and molecular detection of the qacA, qacB, and qacC genes

All 19 isolates were susceptible to a disinfectant containing QAC agent lauryl dimethyl benzyl ammonium bromide. 
Table 2 Antibiotic susceptibility profiles of carbapenem-resistant K. pneumoniae isolates from a Venezuelan Hospital

\begin{tabular}{|c|c|c|c|c|c|c|}
\hline Profile:Isolates & CM & AK & CIP & TE & TYG & $\begin{array}{l}\% \text { of isolates } \\
\text { belonging profile }\end{array}$ \\
\hline 1: ANZ2, ANZ4, ANZ6 & $\mathrm{S}$ & $\mathrm{S}$ & $\mathrm{R}$ & $\mathrm{S}$ & $\mathrm{s}$ & 15.8 \\
\hline 2: ANZ8, ANZ11, ANZ12, ANZ13 & S & $S$ & $\mathrm{R}$ & $\mathrm{R}$ & s & 21.0 \\
\hline 3: ANZ10 & S & $\mathrm{R}$ & S & $\mathrm{R}$ & S & 5.3 \\
\hline 4: ANZ1, ANZ3, ANZ19 & S & $\mathrm{R}$ & $\mathrm{R}$ & $\mathrm{R}$ & s & 15.8 \\
\hline 5: ANZ5, ANZ7, ANZ9, ANZ14 & $\mathrm{R}$ & $\mathrm{R}$ & $\mathrm{R}$ & $\mathrm{R}$ & S & 21.0 \\
\hline 6: ANZ16 & $\mathrm{R}$ & $\mathrm{R}$ & $\mathrm{R}$ & $\mathrm{R}$ & - & 5.3 \\
\hline 7: ANZ17, ANZ18, ANZ21 & $\mathrm{R}$ & $\mathrm{R}$ & $\mathrm{R}$ & $\mathrm{R}$ & $\mathrm{R}$ & 15.8 \\
\hline
\end{tabular}

All strains were resistant to imipenem, meropenem, and trimethoprim-sulfamethoxazole

CM chloramphenicol, AK amikacin, CIP Ciprofloxacin, TE tetracycline, TGC tigecycline, (-) no data

The $q a c \mathrm{~A}, q a c \mathrm{~B}$ and $q a c \mathrm{C}$ genes, implicated in resistance to this type of disinfectants, could not be amplified from any of the isolates.

\section{Molecular genotyping}

The REP-PCR technique produced very similar patterns from all $19 \mathrm{~K}$. pneumoniae isolates. PCR amplification and sequencing of the seven genes [22] used for MLST produced identical profiles from all 19 strains. Comparison with the Klebsiella pneumoniae MLST website (http:// bigsdb.pasteur.fr/klebsiella/klebsiella.html) revealed that this MLST profile is characteristic of sequence type, ST833 (100 \%, $n=19 / 19)$ (Fig. 1).

\section{Plasmid analysis}

Plasmid DNA was isolated from all 19 isolates, and the plasmid profiles are shown in Fig. 2. It appears that there are some similarly sized plasmids that are present in almost all of the 19 isolates. These shared plasmids could carry the located $b l a_{\mathrm{KPC}-2}, b l a_{\mathrm{VIM}-2}$, addA2 and qac $\Delta \mathrm{E}$ genes, which have been commonly found in class 1 integrons within transposons carried on plasmids [27-30].

\section{Discussion}

We report 19 carbapenem reistant K. pneumoniae strains isolated from the pediatrics service of a hospital in Venezuela that co-harbor both $b l a_{\mathrm{KPC}}$ and $b l a_{\mathrm{VIM}}$ genes. All 19 strains appear to have identical Rep-PCR profiles, and by MLST all appear to belong to ST833, suggesting that this resistant strain has become endemic in the pediatric service, especially in the neonatal units of this hospital, where 12 of the strains were isolated. The limited patient information available and irreversibly anonymous nature of the strains did not permit retrospective analysis of the patients to exclude the possibility that some represented colonization or transient carrier

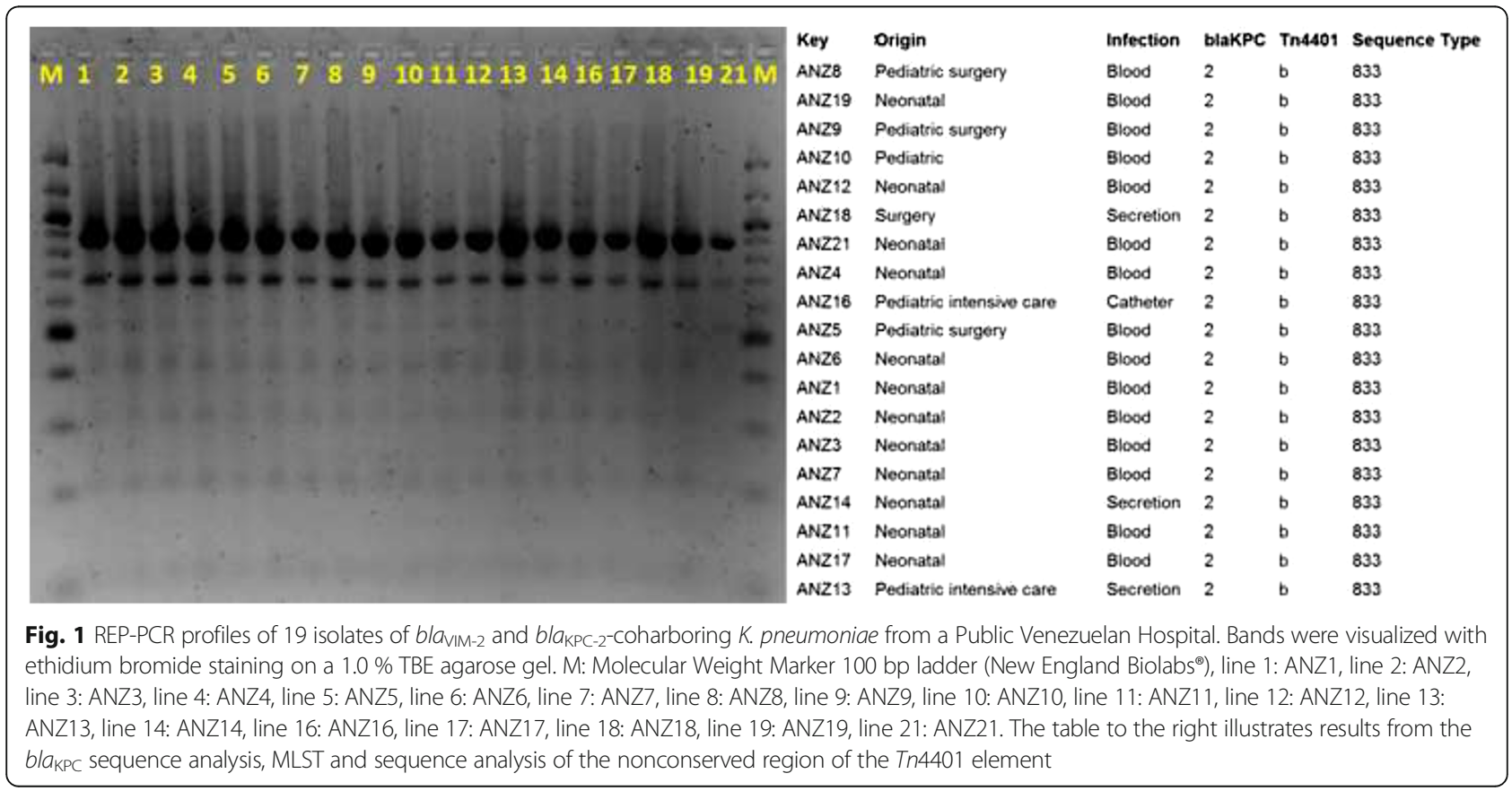


states with KPC-producing $K$. pneumoniae. This seems unlikely, as 15 of the 19 strains were isolated from blood cultures, suggesting they were associated with severe infections. Cross contamination also seems unlikely as the isolates showed seven different profiles of resistance to other antibiotics.

There are no official data available about epidemiological monitoring of bacteria causing nosocomial infections in Venezuelan hospitals. The only surveillance program that provides data about antimicrobial resistance in Venezuela is PROVENRA (http://provenra.cloudapp.net/), a private initiative with information on antibiotic resistance from 1998 to 2012. The information is collected from microbiology laboratories in 46 hospitals nationwide, but does not include the "Dr. Luis Razetti" hospital studied in the present report. According to data reported for 2012 on the PROVENRA webpage, $72 \%$ of $K$. pneumoniae isolated in neonatology services were resistant to ertapenem and $65 \%$ were resistant to meropenem and imipenem (http://provenra.cloudapp.net/). This high prevalence of resistance was confirmed in our study.

Other studies have described carbapenem resistance in Venezuela. Fernández-Canigia and Dowziki in 2012 [31] presented data from the Latin American region on Gram-negative isolates used in the Tigecycline Evaluation and Surveillance Trial (T.E.S.T.). They describe decreasing susceptibility to carbapenems among ESBL producing $K$. pneumoniae in the Latin America countries studied, but found that $90.3 \%$ of Venezuelan strains were sensitive to meropenem. Jones et al. [32] reported the results of a resistance surveillance program monitoring antimicrobial susceptibility patterns in Latin America in which only $15 \%$ of Klebsiella isolates were carbapenem-resistant. Finally, Kazmierczak et al. [33] analyzed Gram-negative pathogens collected from 40 countries, including Venezuela, as part of a global surveillance study in 2012-2014. Carbapenem nonsusceptible Enterobacteriaceae were characterized for bla genes encoding MBLs and serine $\beta$-lactamases variants with PCR and sequencing. In the strains from Venezuela there was one isolate of $K$. pneumoniae containing NDM-1 and one isolate of $P$. aeruginosa carrying VIM-2 [33].

The KPC-2 allele, one of 21 variants of the bla $a_{\text {KPC }}$ gene, was found in all our $19 \mathrm{~K}$. pneumoniae isolates and is one of the most extensively distributed worldwide [34], including in the South American countries of Colombia [35, 36] Brazil [37-40] Argentina [41, 42]. In Venezuela [43, 44], a KPC-2-producing $K$. oxytoca was isolated from a pediatric patient in the state of Mérida [44], but to our knowledge, KPC genes have not been previously reported in Venezuelan K. pneumoniae isolates.

In addition to the KPC-2 gene, all of our 19 isolates also carried the VIM-2-carbapenemase. The bla $a_{\mathrm{VIM}}$ gene is extensively distributed worldwide, with VIM-2 the most widespread variant [45]. Endemicity of VIM enzymes has been reported in Greece, Taiwan, and Japan [46, 47], although outbreaks and single strains of VIM producers have been reported in many other countries including the Latin American countries of México, Argentina, Colombia and Venezuela [45]. In Venezuela the $b l a_{\mathrm{VIM}}$ gene was previously found in clinical isolates of Pseudomonas aeruginosa [48, 49], and Marcano et al. [50] reported VIM-producing carbapenem-resistant $K$. pneumoniae isolated from the urine of a 7-year-old girl hospitalized at the "Hospital de Niños J. M. de los Ríos" in Caracas, Venezuela.

Strains carrying both $b l a_{\mathrm{KPC}}$ and $b l a_{\mathrm{VIM}}$ carbapenemases have been previously reported in Greece [1, 51-54] Colombia [55], Germany [56], Italy [6], and Spain [57]. In Venezuela the two carbapenemases have only been

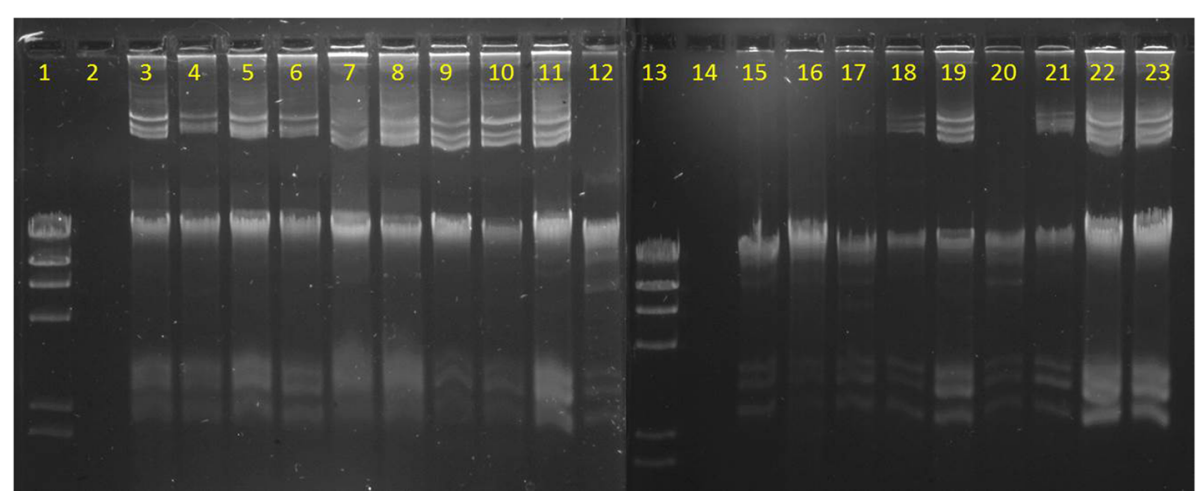

Fig. 2 Plasmidic DNA profile of 19 isolates from a Public Venezuelan Hospital. Bands were visualized with ethidium bromide staining on a $0.7 \%$ TBE agarose gel. Line 1: 100 bp ladder (New England Biolabs ${ }^{\oplus}$ ), line 2: Escherichia coli XL1-Blue (negative control), line 3: ANZ1, line 4: ANZ2, line 5: ANZ3, line 6: ANZ4, line 7: ANZ5, line 8: ANZ6, line 9: ANZ7, line 10: ANZ8, line 11: ANZ9, line 12: ANZ10, line 13: 100 bp ladder (New England Biolabs $)^{\oplus}$, line 14: Escherichia coli XL1-Blue (negative control), line 15: ANZ11, line 16: ANZ12, line 17: ANZ13, line 18: ANZ14, line 19: ANZ16, line 20: ANZ17, line 21: ANZ18, line 22: ANZ19, line 23: ANZ21 
reported together in a multiply resistant strain of Enterobacter cloacae [58] isolated from the urine of a 83-yearold patient in a hospital in the city of Cumaná, which is only about 90 miles from hospital we studied. It might be interesting to know whether both the $E$. cloacae and $K$. pneumoniae isolates could be carrying these carbapenemase genes within the same transferable genetic context.

Class 1 integrons are the most common integron type present in clinical isolates of the Enterobacteriaceae, and are increasingly detected in isolates of $K$. pneumoniae. The gene cassettes most frequently identified within class 1 integrons in Enterobacteriaceae are those encoding resistance to streptomycin (aadA) and trimethoprim $(d f r A)[59,60]$. By PCR we found that $19 \mathrm{~K}$. pneumoniae strains contained the addA2 gene within the $5^{\prime} \mathrm{CS}-3^{\prime} \mathrm{CS}$ region of the integron. We did not look for the presence of the $d f r A$ gene, but all 19 strains were resistant to trimethoprim-sulfamethoxazole. The qac $\Delta \mathrm{E}$ gene, which has also been associated with class 1 integrons [61] was amplified from all 19 isolates.

KPC genes are often found within a transposonassociated element, $\operatorname{Tn} 4401$ [7]. $T n 4401$ possesses genes encoding a transposase $(\operatorname{tnp} \mathrm{A})$ and a resolvase $(\operatorname{tnp} \mathrm{R})$, and has been characterized as an active transposon that is able to mobilize the $b l a_{\mathrm{KPC}}$ genes at high frequency without target specificity [7, 25]. In all 19 strains in this study the $b l a_{\mathrm{KPC}-2}$ genes appeared to be within a Tn3based structure consistent with the Tn4401 isoform ' $\mathrm{b}$ ' [62], which has been observed in Greece [63], Colombia [14], Brazil [64] and the USA. Similar to the report by Pereira et al. [64] the inverted repeat sequences of the flanking regions were not amplified in our isolates, suggesting that their insertion sites may be different from those of K. pneumoniae YC described by Naas et al. [7].

The KPC and VIM genes are generally found on plasmids [65], and the plasmids profiles from all 19 strains contained similar bands, suggesting that the integron containing the carbapenemase genes could be present within a transposable element on a common plasmid, but further studies are needed to confirm this possibility.

All 19 isolates evaluated in this study demonstrated similar patterns with REP-PCR analysis, and by MLST all belonged to ST833, a genotype that has only been reported in Israel [28] and Trieste, Italy [29]. Interestingly, the ST833 K. pneumoniae strain isolated in the Trieste Pediatric Hospital was from a blood culture of a 3-yearold patient transferred from a Venezuelan hospital to undergo marrow transplantation [29].

We have not found any previous studies describing MLST characterization of $K$. pneumoniae strains isolated in Venezuela, but we have used MLST to analyze the strains of KPC-producing K. pneumoniae in a few other hospitals in the country (manuscripts submitted). Although the other hospitals always contained a variety of sequence types, we found isolates belonging to ST833 in hospitals in two other Venezuelan states-Zulia and the Capital District. These are in the west and center of the country, respectively, and distant from hospital studied in the current report, which is located in the eastern state of Anzoátegui. From our albeit limited sampling, it appears that the carbapenem resistant $K$. pneumoniae ST833 strain could be extensively distributed throughout the country. Perhaps a Venezuelan patient acquired the ST833 strain as an infection or colonization while hospitalized in Israel and then returned to Venezuela, where it subsequently disseminated throughout the country with the movements of patients and health care staff.

ST833 is part of the 258 clonal complex, and the ST833 allelic profile (3-3-1-1-1-1-12) differs from ST258 only in the ton $\mathrm{B}$ allele. The clonal complex CC258 is the dominant and most successful KPC producing strains as has spread widely and rapidly across the world [30,66], although the reasons for its apparent advantage have yet to be completely explained facilitated by its production of proteins involved in cell motility, secretion and DNA repair and modification [67-69].

Disinfectants containing QACs are commonly used in Venezuelan hospitals, and therefore the presence of QAC resistance would complicate efforts to reduce the prevalence of this ST833 strain. Fortunately, all strains were phenotypically sensitive to the QAC disinfectant and we could not amplify the $q a c \mathrm{~A}, q a c \mathrm{~B}$ [15] or $q a c \mathrm{C}$ genes $[16,17]$ which have all been associated with QAC resistance. Nevertheless, the use of QAC disinfectants is clearly only a minor part of the measures that are required to control nosocomial infections.

Venezuelan medical personnel are keenly aware that carbapenem-resistant K. pneumoniae have become a frequent cause of nosocomial infections in several hospitals in different Venezuelan cities [8]. We hope that the molecular epidemiology provided by this study can aid in tracking the presence and dissemination of the strains involved, and thereby contribute to the vigilance and surveillance required to effectively treat them and to reduce their presence.

\section{Conclusions}

Molecular characterization of 19 carbapenem-resistant K. pneumoniae strains isolated from pediatric patients in a large public hospital in Anzoátegui, Venezuela, revealed that all contained the $b l a_{\mathrm{KPC}-2}$ and $b l a_{\mathrm{VIM}-2}$ genes, encoding serine and metallo carbapenemases, respectively. MLST analysis showed that all 19 strains belong to ST833, suggesting an alarming endemic presence of this strain throughout the hospital's pediatric service, but particularly in the neonatal units. 


\section{Additional file}

Additional file 1: Table S1. Oligonucleotides used for PCR of carbapenemase-resistant Klebsiella pneumoniae isolates from a Hospital in Venezuela. (DOC $77 \mathrm{~kb}$ )

\section{Abbreviations}

AK: Amikacin; bp: Base-pair; CC: Clonal complex; CIP: Ciprofloxacin; CLSI: Clinical and Laboratory Standards Institute; CM: Chloramphenicol; CS: Conserved-segment; DNA: Deoxyribonucleic acid; Dr: Doctor; IMP: Imienemase; IS: Insertion sequences; KPC: Klebsiella pneumoniae Carbapenemase; MBL: Metallo-ß-lactamase; MLST: Multi-Locus Sequence Typing; NCBI: National Center for Biotechnology Information; NDM: New Delhi Metallo- $\beta$-lactamase; PCR: Polymerase chain reaction; QAC: Quaternary Ammonium Compounds; REP-PCR: Repetitive Element Palindromic Polymerase Chain Reaction; ST: Sequence type; TE: Tetracycline; TGC: Tigecycline; Tn: Transposon; UPMG: Unweighted pair group method; VIM: Verona Integron-ecoded Metallo- $\beta$-lactamase;

\section{Acknowledgments}

We thank the team of curators of the Institut Pasteur MLST and whole genome MLST for collating the databases and making them publicly available at http://bigsdb.pasteur.fr/klebsiella/klebsiella.html". We also thank to Henry Sosa, Loma Abdulkhalek and Rohan Pinto for initiating this study as an undergraduate thesis.

\section{Funding}

This work was supported by research grants from Instituto Venezolano de Investigaciones Científicas (Number 1237), Caracas, Venezuela.

\section{Availability of data and materials}

Contained within the manuscript.

\section{Authors' contributions}

$A F, Y R$, EF and AG performed the experiments; AF, EF, AG, HT contributed reagents/materials/analysis tools; $A F$ and $H T$ conceived and designed the experiments, analysed the data and wrote and revised the manuscript. All authors read and approved the final manuscript.

\section{Competing interests}

The authors declare that they have no competing interests.

\section{Consent for publication}

Not applicable.

\section{Ethics statement}

Not required.

\section{Author details}

'Laboratorio de Genética Molecular, Centro de Microbiología y Biología Celular, Instituto Venezolano de Investigaciones Científicas, Caracas, Venezuela. ${ }^{2}$ Laboratorio B, Dirección de Energía y Ambiente, Instituto de Estudios Avanzados, Caracas, Venezuela. ${ }^{3}$ Servicio de Laboratorio Clínico de anexo pediátrico "Dr. Rafael Tobías Guevara" del Complejo Hospitalario Universitario "Dr. Luis Razetti", Barcelona, Venezuela.

Received: 26 September 2015 Accepted: 12 October 2016 Published online: 22 October 2016

\section{References}

1. Meletis G, Tzampaz E, Protonotariou E, Sofianou D. Emergence of Klebsiella pneumoniae carrying bla(VIM) and bla(KPC) genes. Hippokratia. 2010;14(2):139-40.

2. Nordmann P, Cuzon G, Naas T. The real threat of Klebsiella pneumoniae carbapenemase-producing bacteria. Lancet Infect Dis. 2009:9(4):228-36.

3. Cuzon G, Naas T, Demachy MC, Nordmann P. Plasmid-mediated carbapenem-hydrolyzing beta-lactamase KPC-2 in Klebsiella pneumoniae isolate from Greece. Antimicrob Agents Chemother. 2008;52(2):796-7.

4. Pournaras $S$, Protonotariou E, Voulgari E, Kristo I, Dimitroulia E, Vitti D, Tsalidou M, Maniatis AN, Tsakris A, Sofianou D. Clonal spread of KPC-2 carbapenemase-producing Klebsiella pneumoniae strains in Greece. J Antimicrob Chemother. 2009:64(2):348-52.

5. Patel G, Bonomo RA. Status report on carbapenemases: challenges and prospects. Expert Rev Anti Infect Ther. 2011;9(5):555-70.

6. Perilli M, Bottoni C, Grimaldi A, Segatore B, Celenza G, Mariani M, Bellio P, Frascaria P. Amicosante G. Carbapenem-resistant Klebsiella pneumoniae harbouring blaKPC-3 and blaVIM-2 from central Italy. Diagn Microbiol Infect Dis. 2013;75(2):218-21.

7. Naas T, Cuzon G, Villegas MV, Lartigue MF, Quinn JP, Nordmann P. Genetic structures at the origin of acquisition of the beta-lactamase bla KPC gene. Antimicrob Agents Chemother. 2008;52(4):1257-63.

8. Marcano D, De Jesus A, Hernandez L, Torres L. Frequency of enzymes associated with reduced sensitivity to beta-lactam antibiotics in enterobacteria isolates, Caracas, Venezuela. Rev Panam Salud Publica. 2011; 30(6):529-34.

9. CLSI. Performance standards for antimicrobial susceptibility testing. In: 24th International Supplement M100-S24, Clinical and Laboratory Standards Institute, vol. 34. Wayne: CLSI; 2014. p. 50-60.

10. Tsakris A, Poulou A, Themeli-Digalaki K, Voulgari E, Pittaras T, Sofianou D, Pournaras S, Petropoulou D. Use of boronic acid disk tests to detect extended- spectrum beta-lactamases in clinical isolates of KPC carbapenemase-possessing enterobacteriaceae. J Clin Microbiol. 2009; 47(11):3420-6.

11. Wang L, Gu H, Lu X. Rapid low-cost detection of Klebsiella pneumoniae carbapenemase genes by internally controlled real-time PCR. J Microbio Methods. 2012:91(3):361-3.

12. Bradford PA, Bratu S, Urban C, Visalli M, Mariano N, Landman D, Rahal Jر, Brooks S, Cebular S, Quale J. Emergence of carbapenem-resistant Klebsiella species possessing the class A carbapenem-hydrolyzing KPC-2 and inhibitor-resistant TEM-30 beta-lactamases in New York City. Clin Infect Dis. 2004;39(1):55-60.

13. Poirel L, Walsh TR, Cuvillier V, Nordmann P. Multiplex PCR for detection of acquired carbapenemase genes. Diagn Microbiol Infect Dis. 2011; 70(1):119-23.

14. Cuzon G, Naas T, Truong H, Villegas MV, Wisell KT, Carmeli Y, Gales AC, Venezia SN, Quinn JP, Nordmann P. Worldwide diversity of Klebsiella pneumoniae that produce beta-lactamase blaKPC-2 gene. Emerg Infect Dis. 2010;16(9):1349-56.

15. Wang C, Cai P, Guo Y, Mi Z. Distribution of the antiseptic-resistance genes qacEDelta1 in 331 clinical isolates of Pseudomonas aeruginosa in China. J Hosp Infect. 2007:66(1):93-5.

16. Levesque $C$, Piche $L$, Larose $C$, Roy PH. PCR mapping of integrons reveals several novel combinations of resistance genes. Antimicrob Agents Chemother. 1995;39(1):185-91.

17. Mayer S, Boos M, Beyer A, Fluit AC, Schmitz FJ. Distribution of the antiseptic resistance genes qacA, qacB and qacC in 497 methicillin-resistant and -susceptible European isolates of Staphylococcus aureus. J Antimicrob Chemother. 2001;47(6):896-7.

18. Kawamura-Sato $\mathrm{K}$, Wachino J, Kondo $\mathrm{T}$, Ito $\mathrm{H}$, Arakawa $\mathrm{Y}$. Reduction of disinfectant bactericidal activities in clinically isolated Acinetobacter species in the presence of organic material. J Antimicrob Chemother. 2008;61(3):568-76.

19. Ramos Y, Alonso G. Evaluación de la resistencia a agentes desinfectantes en bacterias aisladas de ambientes naturales. Rev Soc Venez Microbiol. 2011; 31(2):130-7.

20. Chalbaud A, Ramos Y, Alonso G. Antibiotic and disinfectant resistance in Acinetobacter baumannii genotyped isolates from the Caracas University Hospital. In: Microbes in applied research: current advances and challenges. Spain: World Scientific Publishing Co. Pte. Ltd; 2012. p. 481-5.

21. Versalovic J, Koeuth T, Lupski JR. Distribution of repetitive DNA sequences in eubacteria and application to fingerprinting of bacterial genomes. Nucleic Acids Res. 1991:19(24):6823-31.

22. Diancourt L, Passet V, Verhoef J, Grimont PA, Brisse S. Multilocus sequence typing of Klebsiella pneumoniae nosocomial isolates. J Clin Microbiol. 2005; 43(8):4178-82

23. Kieser T. Factors affecting the isolation of CCC DNA from Streptomyces lividans and Escherichia coli. Plasmid. 1984;12(1):19-36.

24. Naas T, Cuzon G, Truong HV, Nordmann P. Role of ISKpn7 and deletions in blaKPC gene expression. Antimicrob Agents Chemother. 2012;56(9):4753-9.

25. Bryant KA, Van Schooneveld TC, Thapa I, Bastola D, Williams LO, Safranek TJ, Hinrichs SH, Rupp ME, Fey PD. KPC-4 Is encoded within a truncated Tn4401 
in an IncL/M plasmid, pNE1280, isolated from Enterobacter cloacae and Serratia marcescens. Antimicrob Agents Chemother. 2013;57(1):37-41.

26. Pereira CA, Marra AR, Camargo LF, Pignatari AC, Sukiennik T, Behar PR, Medeiros EA, Ribeiro J, Girao E, Correa L, et al. Nosocomial bloodstream infections in Brazilian pediatric patients: microbiology, epidemiology, and clinical features. PLoS One. 2013;8(7):e68144.

27. Nobari S, Shahcheraghi F, Rahmati Ghezelgeh F, Valizadeh B. Molecular characterization of carbapenem-resistant strains of Klebsiella pneumoniae isolated from Iranian patients: first identification of blaKPC gene in Iran. Microb Drug Resist. 2014;20(4):285-93.

28. Baraniak A, Izdebski R, Fiett J, Sadowy E, Adler A, Kazma M, Salomon J, Lawrence C, Rossini A, Salvia A, et al. Comparative population analysis of Klebsiella pneumoniae strains with extended-spectrum beta-lactamases colonizing patients in rehabilitation centers in four countries. Antimicrob Agents Chemother. 2013;57(4):1992-7.

29. Garbari L, Busetti M, Dolzani L, Petix V, Knezevich A, Bressan R, Gionechetti F, Tonin EA, Lagatolla C. pKBuS13, a KPC-2 encoding plasmid from Klebsiella pneumoniae Sequence Type 833, carrying Tn4401b inserted into a Xer sitespecific recombination locus. Antimicrob Agents Chemother. 2015;59:5226-31.

30. Qi Y, Wei Z, Ji S, Du X, Shen P, Yu Y. ST11, the dominant clone of KPCproducing Klebsiella pneumoniae in China. J Antimicrob Chemother. 2011; 66(2):307-12.

31. Fernandez-Canigia L, Dowzicky MJ. Susceptibility of important Gramnegative pathogens to tigecycline and other antibiotics in Latin America between 2004 and 2010. Ann Clin Microbiol Antimicrob. 2012;11:29.

32. Jones RN, Guzman-Blanco M, Gales AC, Gallegos B, Castro AL, Martino MD, Vega S, Zurita J, Cepparulo M, Castanheira M. Susceptibility rates in Latin American nations: report from a regional resistance surveillance program (2011). Braz J Infect Dis. 2013;17(6):672-81

33. Kazmierczak KM, Rabine $\mathrm{S}$, Hackel M, McLaughlin RE, Biedenbach DJ, Bouchillon SK, Sahm DF, Bradford PA. Multiyear, multinational survey of the incidence and global distribution of metallo-beta-lactamase-producing Enterobacteriaceae and Pseudomonas aeruginosa. Antimicrob Agents Chemother. 2015;60(2):1067-78.

34. Munoz-Price LS, Poirel L, Bonomo RA, Schwaber MJ, Daikos GL, Cormican M, Cornaglia G, Garau J, Gniadkowski M, Hayden MK, et al. Clinical epidemiology of the global expansion of Klebsiella pneumoniae carbapenemases. Lancet Infect Dis. 2013;13(9):785-96.

35. Mojica MF, Correa A, Vargas DA, Maya JJ, Montealegre MC, Rojas LJ, Ruiz SJ, Quinn JP, Villegas MV. Molecular correlates of the spread of KPC-producing Enterobacteriaceae in Colombia. Int J Antimicrob Agents. 2012;40(3):277-9.

36. Villegas MV, Lolans K, Correa A, Suarez CJ, Lopez JA, Vallejo M, Quinn JP. First detection of the plasmid-mediated class A carbapenemase KPC-2 in clinical isolates of Klebsiella pneumoniae from South America. Antimicrob Agents Chemother. 2006;50(8):2880-2.

37. Gales AC, Castanheira M, Jones RN, Sader HS. Antimicrobial resistance among Gram-negative bacilli isolated from Latin America: results from SENTRY Antimicrobial Surveillance Program (Latin America, 2008-2010). Diagn Microbiol Infect Dis. 2012;73(4):354-60.

38. Monteiro J, Santos AF, Asensi MD, Peirano G, Gales AC. First report of KPC-2producing Klebsiella pneumoniae strains in Brazil. Antimicrob Agents Chemother. 2009:53(1):333-4.

39. Seki LM, Pereira PS, de Souza Mda P, Conceicao Mde S, Marques EA, Porto CO, Colnago EM, Alves Cde F, Gomes D, Assef AP, et al. Molecular epidemiology of KPC-2- producing Klebsiella pneumoniae isolates in Brazil: the predominance of sequence type 437. Diagn Microbiol Infect Dis. 2011;70(2):274-7.

40. Chagas TP, Seki LM, da Silva DM, Asensi MD. Occurrence of KPC-2producing Klebsiella pneumoniae strains in hospital wastewater. J Hosp Infect. 2011;77(3):281.

41. Pasteran FG, Otaegui L, Guerriero L, Radice G, Maggiora R, Rapoport M, Faccone D, Di Martino A, Galas M. Klebsiella pneumoniae Carbapenemase-2, Buenos Aires, Argentina. Emerg Infect Dis. 2008;14(7):1178-80.

42. Gomez SA, Pasteran FG, Faccone D, Tijet N, Rapoport M, Lucero C, Lastovetska O, Albornoz E, Galas M, Melano RG, et al. Clonal dissemination of Klebsiella pneumoniae ST258 harbouring KPC-2 in Argentina. Clin Microbiol Infect. 2011:17(10):1520-4.

43. Villegas MV, Kattan JN, Quinteros MG, Casellas JM. Prevalence of extendedspectrum beta-lactamases in South America. Clin Microbiol Infect. 2008;14 Suppl 1:154-8.
44. Labrador I, Araque M. First description of KPC-2-producing klebsiella oxytoca isolated from a pediatric patient with nosocomial pneumonia in Venezuela. Case Rep Infect Dis. 2014;2014:434987.

45. Nordmann P, Naas T, Poirel L. Global spread of Carbapenemase-producing Enterobacteriaceae. Emerg Infect Dis. 2011;17(10):1791-8.

46. Queenan AM, Bush K. Carbapenemases: the versatile beta-lactamases. Clin Microbiol Rev. 2007;20(3):440-58. table of contents.

47. Walsh TR, Toleman MA, Poirel L, Nordmann P. Metallo-beta-lactamases: the quiet before the storm? Clin Microbiol Rev. 2005;18(2):306-25.

48. Mendes RE, Castanheira M, Garcia P, Guzman M, Toleman MA, Walsh TR, Jones RN, Program SAS. First isolation of bla(VIM-2) in Latin America: report from the SENTRY Antimicrobial Surveillance Program. Antimicrob Agents Chemother. 2004;48(4):1433-4.

49. Sánchez D, Marcano D, Spadola E, León L, Payares D, Ugarte C, Salgado N, Maggi G, Guevara A, Torres S, et al. Metaloenzimas tipo VIM Detectadas en Aislamientos Clínicos en Pseudomonas aeruginosa en Cuatro Hospitales en Venezuela. Revista Cientifica del Instituto Nacional de Hlgiene "Rafael Rangel". In Press.

50. Marcano D, Pasteran F, Rapoport M, Faccone D, Ugarte C, Salgado N, Payares D, Spadola E, Lopez Y, Maggi G, et al. First isolation of a VIMproducing Klebsiella pneumoniae from a seven-year-old child in Venezuela. J Infect Dev Ctries. 2008;2(3):241-4.

51. Giakkoupi P, Pappa O, Polemis M, Vatopoulos AC, Miriagou V, Zioga A, Papagiannitsis CC, Tzouvelekis LS. Emerging Klebsiella pneumoniae isolates coproducing KPC-2 and VIM-1 carbapenemases. Antimicrob Agents Chemother. 2009;53(9):4048-50

52. Zioga A, Miriagou V, Tzelepi E, Douzinas E, Tsakiri M, Legakis NJ, Daikos GL, Tzouvelekis LS. The ongoing challenge of acquired carbapenemases: a hospital outbreak of Klebsiella pneumoniae simultaneously producing VIM-1 and KPC-2. Int J Antimicrob Agents. 2010;36(2):190-1.

53. Pournaras S, Poulou A, Voulgari E, Vrioni G, Kristo I, Tsakris A. Detection of the new metallo-beta-lactamase VIM-19 along with KPC-2, CMY-2 and CTXM-15 in Klebsiella pneumoniae. J Antimicrob Chemother. 2010;65(8):1604-7.

54. Papagiannitsis CC, Giakkoupi P, Vatopoulos AC, Tryfinopoulou K, Miriagou V, Tzouvelekis LS. Emergence of Klebsiella pneumoniae of a novel sequence type (ST383) producing VIM-4, KPC-2 and CMY-4 beta-lactamases. Int J Antimicrob Agents. 2010;36(6):573-4

55. Montealegre MC, Correa A, Briceno DF, Rosas NC, De La Cadena E, Ruiz SJ, Mojica MF, Camargo RD, Zuluaga I, Marin A, et al. Novel VIM metallo-betalactamase variant, VIM-24, from a Klebsiella pneumoniae isolate from Colombia. Antimicrob Agents Chemother. 2011;55(5):2428-30.

56. Steinmann J, Kaase M, Gatermann S, Popp W, Steinmann E, Damman M, Paul A, Saner F, Buer J, Rath P. Outbreak due to a Klebsiella pneumoniae strain harbouring KPC-2 and VIM-1 in a German university hospital, July 2010 to January 2011. Euro Surveill. 2011;16:33.

57. Pena I, Picazo JJ, Rodriguez-Avial C, Rodriguez-Avial I. Carbapenemaseproducing Enterobacteriaceae in a tertiary hospital in Madrid, Spain: high percentage of colistin resistance among VIM-1-producing Klebsiella pneumoniae ST11 isolates. Int J Antimicrob Agents. 2014;43(5):460-4.

58. Martinez D, Marcano D, Rodulfo H, Salgado N, Cuaical N, Rodriguez L, Cana L, Medina B, Guzman M, De Donato M. KPC and VIM producing Enterobacter cloacae strain from a hospital in northeastern Venezuela. Invest Clin. 2015;56(2):182-7.

59. Li B, Hu Y, Wang Q, Yi Y, Woo PC, Jing H, Zhu B, Liu CH. Structural diversity of class 1 integrons and their associated gene cassettes in Klebsiella pneumoniae isolates from a hospital in China. PLoS One. 2013;8(9):e75805.

60. DeLappe N, O'Halloran F, Fanning S, Corbett-Feeney G, Cheasty T, Cormican M. Antimicrobial resistance and genetic diversity of Shigella sonnei isolates from western Ireland, an area of low incidence of infection. J Clin Microbiol. 2003;41(5):1919-24.

61. Santos C, Caetano T, Ferreira S, Ramalheira E, Mendo S. A novel complex class 1 integron found in a Klebsiella pneumoniae isolate from Portugal. Clin Microbiol Infect. 2011;17(7):1036-9.

62. Cuzon G, Naas T, Nordmann P. Functional characterization of Tn4401, a Tn3based transposon involved in blaKPC gene mobilization. Antimicrob Agents Chemother. 2011;55(11):5370-3.

63. Giakkoupi P, Papagiannitsis CC, Miriagou V, Pappa O, Polemis M, Tryfinopoulou K, Tzouvelekis LS, Vatopoulos AC. An update of the evolving epidemic of blaKPC-2-carrying Klebsiella pneumoniae in Greece (2009-10). J Antimicrob Chemother. 2011;66(7):1510-3.

64. Pereira PS, de Araujo CF, Seki LM, Zahner V, Carvalho-Assef AP, Asensi MD. Update of the molecular epidemiology of KPC-2-producing Klebsiella 
pneumoniae in Brazil: spread of clonal complex 11 (ST11, ST437 and ST340). J Antimicrob Chemother. 2013;68(2):312-6.

65. Endimiani A, Carias LL, Hujer AM, Bethel CR, Hujer KM, Perez F, Hutton RA, Fox WR, Hall GS, Jacobs MR, et al. Presence of plasmid-mediated quinolone resistance in Klebsiella pneumoniae isolates possessing blaKPC in the United States. Antimicrob Agents Chemother. 2008;52(7):2680-2.

66. Zhou T, Zhang Y, Li M, Yu X, Sun Y, Xu J. An outbreak of infections caused by extensively drug-resistant Klebsiella pneumoniae strains during a short period of time in a Chinese teaching hospital: epidemiology study and molecular characteristics. Diagn Microbiol Infect Dis. 2015;82(3):240-4.

67. Chmelnitsky I, Shklyar M, Hermesh O, Navon-Venezia S, Edgar R, Carmeli Y. Unique genes identified in the epidemic extremely drug-resistant KPCproducing Klebsiella pneumoniae sequence type 258. J Antimicrob Chemother. 2013;68(1):74-83.

68. Yang J, Ye L, Guo L, Zhao Q, Chen R, Luo Y, Chen Y, Tian S, Zhao J, Shen D, et al. A nosocomial outbreak of KPC-2-producing Klebsiella pneumoniae in a Chinese hospital: dissemination of ST11 and emergence of ST37, ST392 and ST395. Clin Microbiol Infect. 2013;19(11):E509-15.

69. Chen L, Mathema B, Chavda KD, DeLeo FR, Bonomo RA, Kreiswirth BN. Carbapenemase-producing Klebsiella pneumoniae: molecular and genetic decoding. Trends Microbiol. 2014;22(12):686-96.

\section{Submit your next manuscript to BioMed Central} and we will help you at every step:

- We accept pre-submission inquiries

- Our selector tool helps you to find the most relevant journal

- We provide round the clock customer support

- Convenient online submission

- Thorough peer review

- Inclusion in PubMed and all major indexing services

- Maximum visibility for your research

Submit your manuscript at www.biomedcentral.com/submit 